\title{
Efficiency of phonolite as a potassium source for Paiaguás palisadegrass ${ }^{1}$
}

\author{
Carlos Augusto Campos da $\mathrm{Cruz}^{2}$, Valdeci Orioli Júnior², João Victor Silva Bernardes², \\ Mateus Martini Sargentim², Gabriel Augusto Silva², Ana Clara Dutra Kochenborger ${ }^{2}$
}

\section{ABSTRACT}

Potassium chloride $(\mathrm{KCl})$ is the most widely used potassium source to meet crops requirements. However, Brazil's dependence on imports to meet the national demand demonstrates the need to assess the efficiency of other sources of this nutrient. The present study aimed to assess the agronomic efficiency of phonolite in natura and its mixture with a water-soluble source $(\mathrm{KCl})$, for Paiaguás palisadegrass. The experiment was conducted in a greenhouse, with a sandy clay loam typic Hapludox. A completely randomized block design was used, in a $3 \times 5$ factorial scheme, consisting of three $\mathrm{K}$ sources $(\mathrm{KCl}$, phonolite and a $30 \%$ of $\mathrm{KCl}+70 \%$ of phonolite blend) and five doses of the nutrient $\left(0,50,100,150\right.$ and $\left.200 \mathrm{mg} \mathrm{kg}^{-1}\right)$, with four replications. The phonolite doses promoted a linear increase in the dry weight production, albeit inferior to $\mathrm{KCl}$ for all the cuttings, whereas the $\mathrm{KCl}(30 \%)$ and phonolite $(70 \%)$ blend showed a better fertilization efficiency than phonolite alone, which exhibited an intermediate effect. The agronomic efficiency was $29 \%$ for the phonolite alone and $63 \%$ for the blend, and the critical K levels in the soil and shoots were, respectively, $1.4 \mathrm{mmol}_{\mathrm{c}} \mathrm{dm}^{-3}$ and $8.7 \mathrm{~g} \mathrm{~kg}^{-1}$.

KEYWORDS: Urochloa brizantha (Hochst. ex A. Rich.) R. D. Webster, potassium fertilizer, potassium silicate.

\section{INTRODUCTION}

Grasses from the Urochloa genus, such as Urochloa brizantha cv. Paiaguás, have become increasingly important in the Brazilian livestock sector as a food source for ruminants, due to their low nutrient requirements (Moreira et al. 2009, Costa et al. 2010, Germano et al. 2018).

The limited natural fertility of most Brazilian soils (Briguenti et al. 2011) is directly related to the causes of low yield. The Brazilian Savanna contains

\section{RESUMO}

Eficiência de fonolito como

fonte de potássio para capim Paiaguás

Dentre as alternativas para suprir as demandas de $\mathrm{K}$ das culturas, o cloreto de potássio $(\mathrm{KCl})$ é a fonte mais utilizada. Porém, a alta dependência de sua importação para suprir a demanda nacional leva à necessidade de se avaliar a eficiência de outras fontes desse nutriente. Objetivou-se avaliar a eficiência agronômica de fonolito in natura e de sua mistura com uma fonte solúvel em água $(\mathrm{KCl})$, para capim Paiaguás. O experimento foi conduzido em casa-de-vegetação, com Latossolo Vermelho distrófico de textura média, adotando-se delineamento inteiramente casualizado, em esquema fatorial $3 \times 5$, sendo três fontes $(\mathrm{KCl}$, fonolito e mistura de $30 \%$ de $\mathrm{KCl}+70 \%$ de fonolito) e cinco doses $(0 ; 50 ; 100$; 150; e $200 \mathrm{mg} \mathrm{kg}^{-1}$ ) de $\mathrm{K}$, com quatro repetições. As doses de fonolito promoveram aumento linear na produção de massa seca, mas foi inferior ao $\mathrm{KCl}$ em todos os cortes, enquanto a mistura de $\mathrm{KCl}(30 \%)$ e fonolito (70 \%) aumentou a eficiência fertilizante, em relação ao fonolito aplicado exclusivamente, mostrando-se intermediária. A eficiência agronômica foi de 29 e $63 \%$ para o fonolito e a mistura, respectivamente, e os níveis críticos de $\mathrm{K}$ no solo

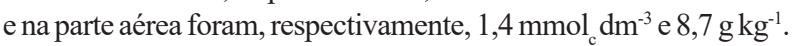

PALAVRAS-CHAVE: Urochloa brizantha (Hochst. ex A. Rich.) R. D. Webster, fertilizante potássico, silicato potássico.

highly weathered soils with a low cation exchange capacity, and most consist predominantly of 1:1 clays, which are naturally $\mathrm{K}$ deficient (Lopes 2005).

Adequate amounts and proportions of nutrients are important for grasses, particularly $\mathrm{K}$, an essential plant nutrient (Benett et al. 2008, Marschner 2012). In general, well-nourished $U$. brizhanta shoots and green leaves exhibit high $\mathrm{K}$ concentrations of 12-30 $\mathrm{g} \mathrm{kg}^{-1}$, during their active growth (Weber et al. 1996). Orioli Júnior \& Coutinho (2009), Megda \& Monteiro (2010) and Morais et al. (2016) observed,

\footnotetext{
${ }^{1}$ Received: Feb. 24, 2021. Accepted: Apr. 26, 2021. Published: July 29, 2021. DOI: 10.1590/1983-40632021v5167857.

${ }^{2}$ Instituto Federal de Educação, Ciência e Tecnologia do Triângulo Mineiro, Uberaba, MG, Brasil.

E-mail/ORCID: carlos.accruz@outlook.com/0000-0001-7802-7471; valdeci@iftm.edu.br/0000-0001-6202-7100; joaovictorsilvabernardes@gmail.com/0000-0001-8522-3358; mateus.sargentim@gmail.com/0000-0002-4782-554X; biel.augusto16@gmail.com/0000-0002-1345-6854; acdkochenborger@gmail.com/0000-0002-3656-1251.
} 
respectively, dry weight increases of 246, 270 and $86 \%$ in $U$. brizantha, as a function of potassium fertilization.

Potassium chloride $(\mathrm{KCl})$ is the potassium source most widely used to meet crop requirements in the Brazilian agricultural sector. Brazil imports approximately $90 \%$ of all the $\mathrm{K}$ it consumes (Ibram 2011). The availability of $K$ sources for agriculture has become a major concern in several countries, due to the small amount of good quality potassium suitable for use as fertilizer (Basak \& Sarkar 2017).

In Brazil, rocks such as verdigris, nepheline syenites and granites are being studied as potential potassium sources (Santos et al. 2015). Heat treated potassium-bearing rock and $\mathrm{KCl}$ were found to have a similar agronomic efficiency (Orioli Júnior \& Coutinho 2009). However, ground nepheline syenite from the Poços de Caldas region of the Minas Gerais state showed to be an inefficient $\mathrm{K}$ source due to the difficulty involved in releasing the nutrient (Siqueira et al. 1985).

The speed and intensity of nutrient release depend on several factors, with mineralogy considered the most important one, in terms of selecting rocks for use in agriculture (Silva et al. 2012). According to Manning (2011), rocks containing the mineral nepheline release $\mathrm{K}$ more easily than those comprised solely of potassium feldspars. Although phonolite contains this component and is the volcanic equivalent of nepheline syenite (Fernandes et al. 2010), research on the agronomic efficiency of this rock is scarce, particularly when applied in the pure form.

It has been suggested that materials insoluble in water that release $\mathrm{K}$ slowly, such as phonolite (Martins et al. 2015), could be mixed with potassium chloride, a highly water-soluble potassium source, to meet initial crop needs for this nutrient (Orioli Júnior \& Coutinho 2009). As such, the hypothesis of this study is that ground phonolite may be used as a $\mathrm{K}$ source for forage grasses. Thus, it aimed to assess the agronomic efficiency of pure phonolite and a mixture of this fertilizer with a water-soluble source $(\mathrm{KCl})$ in Paiaguás palisadegrass, as well as to determine the critical $\mathrm{K}$ level in the soil and shoots.

\section{MATERIAL AND METHODS}

The experiment was carried out in a greenhouse, at the Instituto Federal de Educação,
Ciência e Tecnologia do Triângulo Mineiro, in Uberaba, Minas Gerais state, Brazil (19³9'38.34”S, $47^{\circ} 57^{\prime} 56.84^{\prime \prime} \mathrm{W}$ and altitude of $799 \mathrm{~m}$ ), from January to May 2019. The climate in the region is characterized as Aw (warm tropical), according to the Köppen classification, with cold dry winters and warm wet summers (Beck et al. 2018).

Pots containing $5.0 \mathrm{~kg}$ of soil classified as medium-textured Latossolo Vermelho distrófico (Santos et al. 2018), or sandy clay loam typic Hapludox (USDA 2014), were used. The soil was collected at a depth of $0.40-0.60 \mathrm{~m}$ and exhibited the following chemical attributes: $\mathrm{pH}\left(\mathrm{CaCl}_{2}\right)=4.6 ; \mathrm{OM}=14 \mathrm{~g} \mathrm{dm}^{-3} ; \mathrm{P}($ resin $)=$ $2.7 \mathrm{mg} \mathrm{dm}^{-3} ; \mathrm{K}=0.4 \mathrm{mmol}_{\mathrm{c}} \mathrm{dm}^{-3} ; \mathrm{Ca}=3.3 \mathrm{mmol}_{\mathrm{c}} \mathrm{dm}^{-3}$; $\mathrm{Mg}=0.5 \mathrm{mmol}_{\mathrm{c}} \mathrm{dm}^{-3} ; \mathrm{H}+\mathrm{Al}=29.0 \mathrm{mmol}_{\mathrm{c}} \mathrm{dm}^{-3} ; \mathrm{Al}=$ $1.7 \mathrm{mmol}_{\mathrm{c}} \mathrm{dm}^{-3}$; $\mathrm{CEC}=33.2 \mathrm{mmol}_{\mathrm{c}} \mathrm{dm}^{-3} ; \mathrm{V}=13 \%$. The analyses were performed according to Raij et al. (2001).

A completely randomized block design, in a $3 \times 5$ factorial scheme, with four replications, was used. The treatments consisted of a combination of three $\mathrm{K}$ sources $(\mathrm{KCl}$, phonolite and a $30 \%$ of $\mathrm{KCl}+$ $70 \%$ of phonolite blend) and five doses of the nutrient $\left(0,50,100,150\right.$ and $\left.200 \mathrm{mg} \mathrm{kg}^{-1}\right)$, based on the total $\mathrm{K}$ content in each source. The $\mathrm{KCl}$ contained $60 \%$ of $\mathrm{K}_{2} \mathrm{O}$ and the phonolite exhibited the following composition: total $\mathrm{K}_{2} \mathrm{O}=8 \% ; \mathrm{K}_{2} \mathrm{O}$ soluble in citric acid $\left(20 \mathrm{~g} \mathrm{~L}^{-1}\right.$, at a ratio of $\left.1: 100\right)=1 \%$; and $\mathrm{SiO}_{2}=$ $53.5 \%$. With respect to particle size, $80 \%$ of the product passed through an ABNT 200 sieve (mesh size $=0.075 \mathrm{~mm}$ ). The chemical analyses were conducted in line with Brasil (2017). The fertilizers were applied in powder form and incorporated into the total soil volume of each pot.

Liming was performed at 15 days after the treatment application to increase the base saturation to $50 \%$, using agricultural lime (TNP $=80.5 \%$; $\mathrm{CaO}=36 \%$; and $\mathrm{MgO}=12 \%)$. Next, all the experimental units were fertilized with $100 \mathrm{mg} \mathrm{kg}^{-1}$ of N (urea), $200 \mathrm{mg} \mathrm{kg}^{-1}$ of P (single superphosphate) and $0.1 \mathrm{mg} \mathrm{kg}^{-1}$ of B (boric acid). The same fertilizers were incorporated into the total volume of soil in each pot at the treatment application. Water was then added and the soil incubated for 10 days, after which the soil sampling was performed (70 $\mathrm{g}$ of soil).

Forty Urochloa brizantha (Hochst. ex A. Rich.) R. D. Webster cv. Paiaguás seeds were sown in each pot and thinning was performed at 7 days after emergence (DAE), leaving five plants per pot. 
The pots were watered daily to maintain the soil moisture content at approximately $70 \%$ of maximum water retention capacity, with the amount of water determined by weighing the pots.

At $13 \mathrm{DAE}, 100 \mathrm{mg} \mathrm{kg}^{-1}$ of $\mathrm{N}$ (urea) were applied as topdressing and the first cutting performed at $47 \mathrm{DAE}$, with the second and third ones conducted at 44 days after the previous cutting. The soil sampling was performed immediately after each cutting, collecting $70 \mathrm{~g}$ of soil per pot. After each sampling, $100 \mathrm{mg} \mathrm{kg}^{-1}$ of $\mathrm{N}$ were applied as topdressing, with ammonium sulfate as source after the first cutting and urea after the second one. The number of tillers and leaves in each pot were counted just before cutting.

The plants were cut at $1 \mathrm{~cm}$ above the ground. The plant material was washed, dried in a forced-air oven at $65^{\circ} \mathrm{C}$, for $72 \mathrm{~h}$, weighed to determine the shoot dry weight and ground for $\mathrm{K}$ concentration analysis (Bataglia et al. 1983). The K content and shoot dry weight data were used to calculate the $\mathrm{K}$ accumulation in the plant. Exchangeable $\mathrm{K}$ was determined in each soil sample using a cationexchange resin as extractor (Raij et al. 2001).

Agronomic efficiency was assessed using the method proposed by Goedert et al. (1986), with $\mathrm{KCl}$ as a reference source $(\mathrm{EqKCl})$, calculated as the ratio between the $\mathrm{K}$ doses (in the form of $\mathrm{KCl}$ and the test source) that provided the same yield, converted into percentage: $\operatorname{EqKCl}(\%)=\left(\mathrm{X}_{1} / \mathrm{X}_{2}\right) \times 100$, where $\mathrm{X}_{1}$ is the $\mathrm{KCl}$-based $\mathrm{K}$ dose needed to achieve the maximum yield obtained with the test source and $\mathrm{X}_{2}$ the $\mathrm{K}$ dose needed from the test source to achieve maximum yield. It was determined considering a dose of $200 \mathrm{mg} \mathrm{kg}^{-1}$ of $\mathrm{K}$ for phonolite alone and the fertilizer blend.

The data were submitted to analysis of variance and the means for the K sources compared using the Tukey test. Polynomial regression was applied for $\mathrm{K}$ doses. Unfolding was performed regardless of whether the interaction between the causes of variation was significant. Critical K levels in the plants and soil were determined using the method described by Cate Junior \& Nelson (1971).

\section{RESULTS AND DISCUSSION}

Regardless of the source, higher $\mathrm{K}$ doses resulted in a linear increase in the soil $\mathrm{K}$ content in the first sampling; however, a difference was observed among the sources (Figure 1A). For every $1 \mathrm{mg} \mathrm{kg}^{-1}$ of
$\mathrm{K}$ added, there was an increase of $0.0241 \mathrm{mmol}_{\mathrm{c}} \mathrm{dm}^{-3}$ of $\mathrm{K}$ in the soil for the $\mathrm{KCl}$ source, $0.0016 \mathrm{mmol}_{\mathrm{c}} \mathrm{dm}^{-3}$ for phonolite and $0.0086 \mathrm{mmol} \mathrm{dm}^{-3}$ for the fertilizer blend. Thus, the highest $\mathrm{K}$ dose $\left(200 \mathrm{mg} \mathrm{kg}^{-1}\right)$ resulted in soil $\mathrm{K}$ contents of 5.83, 0.97 and $2.76 \mathrm{mmol}_{\mathrm{c}} \mathrm{dm}^{-3}$, that is, increases of 477,49 and $165 \%$, in relation to the treatment without the nutrient for $\mathrm{KCl}$, phonolite alone and the fertilizer blend, respectively.

These differences are due to the solubility characteristics of each fertilizer. $\mathrm{KCl}$ is highly soluble in water, meaning it dissolves and releases potassium immediately after application. Phonolite, in turn, is insoluble in water and exhibits low solubility in citric acid ( $1 \%$ of the $\mathrm{K}_{2} \mathrm{O}$ it contains). As such, the high lattice energy of the $\mathrm{K}$ atom in potassium-bearing rocks means that the solubilization of phonolite is highly dependent on its interaction with the soil and occurs slowly (Basak et al. 2017).

In the second sampling, the soil $\mathrm{K}$ content increased when the $\mathrm{K}$ dose increased only when $\mathrm{KCl}$ was used (Figure 1B). The low coefficient of determination observed when the data were fit to the mathematical model $\left(\mathrm{R}^{2}=0.32\right)$ is likely related to the variation in the soil $\mathrm{K}$ content between experimental units in a same treatment during the growth cycle, as a function of $\mathrm{K}$ uptake by the plants.

Since the solubilization of phonolite depends on its interaction with the soil, its content was expected to increase over a longer period of contact with the soil. However, this was not the case for either phonolite or the fertilizer blend for the duration of the present study, regardless of the dose applied (Figure 1B).

The lack of effect on the soil $\mathrm{K}$ content for the fertilizer blend in the second soil sampling may be due to the fact that the plants had absorbed all the $\mathrm{K}$ supplied by $\mathrm{KCl}$ ( $30 \%$ of the source) at the initial growth stage, assessed at the first cutting, and the $\mathrm{K}$ in the phonolite ( $70 \%$ of the source) had not yet been released in significant quantities. At the third cutting, there were no differences in the soil $\mathrm{K}$ content as a function of $\mathrm{K}$ doses and sources (Figure 1C).

For the $\mathrm{KCl}$ and fertilizer blend sources, higher $\mathrm{K}$ doses caused a linear increase in the shoot concentration of this nutrient at all the three cuttings. However, with phonolite as a source, the shoot K content only increased with increasing $\mathrm{K}$ doses at the second cutting. Concentrations of the nutrient remained constant for the remaining cuttings (first and third), regardless of the $\mathrm{K}$ dose (Figures 1D, 

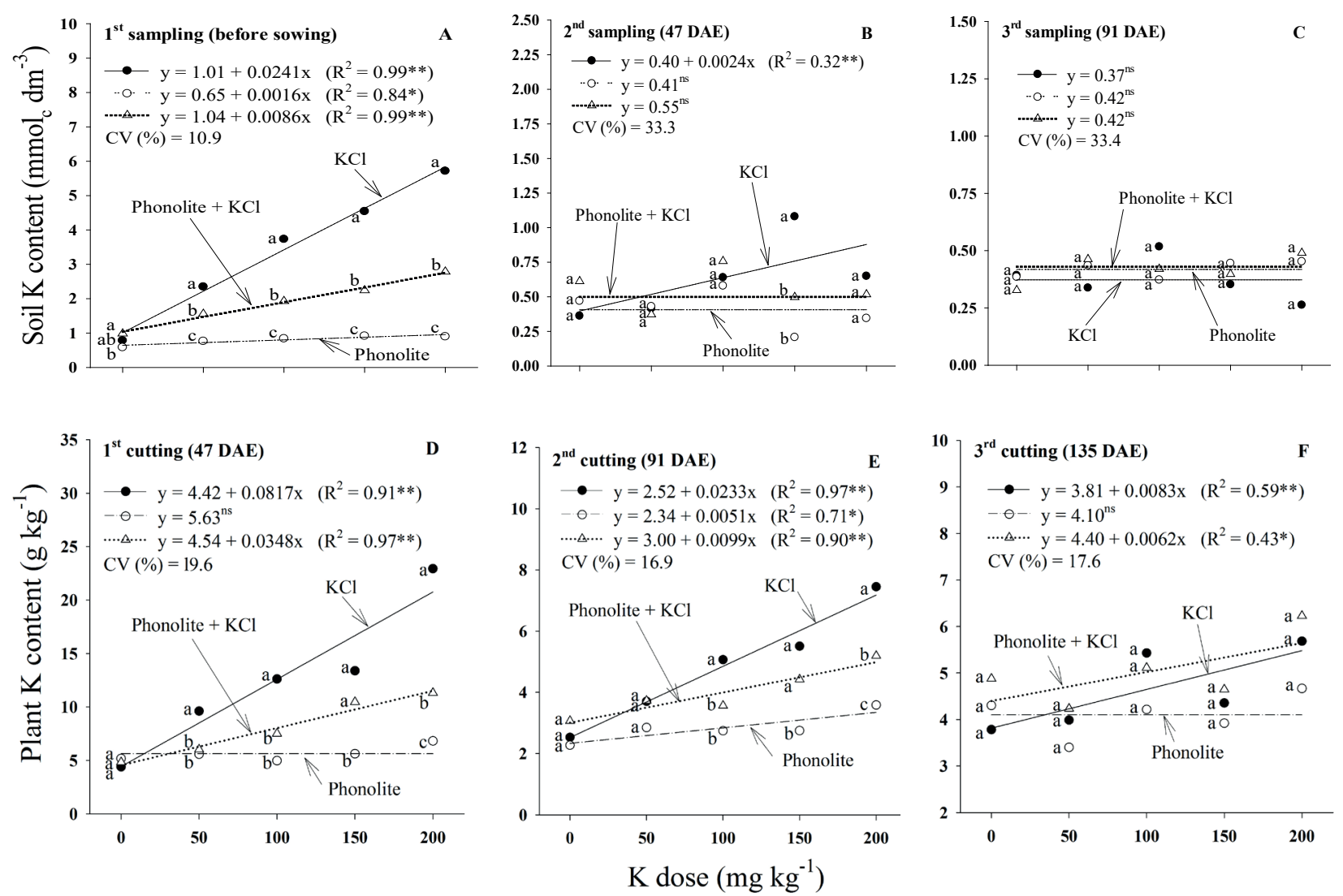

Figure 1. K content in the soil (A, B and C) and shoots (D, E and F) of Paiaguás palisadegrass, as a function of K doses and sources, at three assessment times. Means followed by the same letter within each dose do not differ significantly according to the Tukey test at $5 \%$ of probability. $* *$, ${ }^{*}$ and ${ }^{n s}$ : significant at $1 \%$ and $5 \%$ of probability and not significant, respectively. $\mathrm{CV}(\%)$ : coefficient of variation. DAE: days after emergence.

$1 \mathrm{E}$ and $1 \mathrm{~F})$. Significant differences between the sources were also observed at the first and second cuttings (Figures $1 \mathrm{D}$ and $1 \mathrm{E}$ ), particularly at the highest dose $\left(200 \mathrm{mg} \mathrm{kg}^{-1}\right)$. In this case, the highest $\mathrm{K}$ concentrations in the plants were obtained with $\mathrm{KCl}$ application and the lowest for phonolite, with the fertilizer blend resulting in intermediate values.

The $\mathrm{KCl}$ application at a dose greater than or equal to $93 \mathrm{mg} \mathrm{kg}^{-1}$ of $\mathrm{K}$ at the first cutting led to concentrations of the nutrient considered adequate by Werner et al. (1997), who suggested a sufficiency range of $12-30 \mathrm{~g} \mathrm{~kg}^{-1}$ of $\mathrm{K}$ in $U$. brizantha shoots and leaves.

There was a linear accumulation of $\mathrm{K}$ in the shoots as a function of increased doses of the nutrient at all the cuttings. However, plants fertilized with $\mathrm{KCl}$ absorbed and accumulated more $\mathrm{K}$ than those treated with phonolite at all the cuttings, while the fertilizer blend resulted in intermediate $\mathrm{K}$ accumulation values (Figures 2A, 2B and 2C).
The $\mathrm{K}$ application also increased the dry weight production at all the three cuttings, with differences observed among the sources (Figures 3A, 3B and 3C). At the first two cuttings, particularly at higher $\mathrm{K}$ doses (150 and $200 \mathrm{mg} \mathrm{kg}^{-1}$ ), $\mathrm{KCl}$ produced better yields than those obtained with phonolite, whereas the fertilizer blend resulted in intermediate yields (Figures 3A and 3B). The same dynamic was observed for total yield over the study period (Figure 3D).

For the $\mathrm{KCl}$ application at the third cutting, the two highest $\mathrm{K}$ doses (150 and $200 \mathrm{mg} \mathrm{kg}^{-1}$ ) produced the best results, with intermediate yields recorded for phonolite, when compared to the other sources (Figure 3C). This is likely because there was less $\mathrm{K}$ available in the soil from the $\mathrm{KCl}$ present in the fertilizer blend, as a function of its absorption in previous cycles and the solubilization of only a small portion of the $\mathrm{K}$ in the phonolite. Additionally, the fast increase of the $\mathrm{K}$ concentration in the soil 

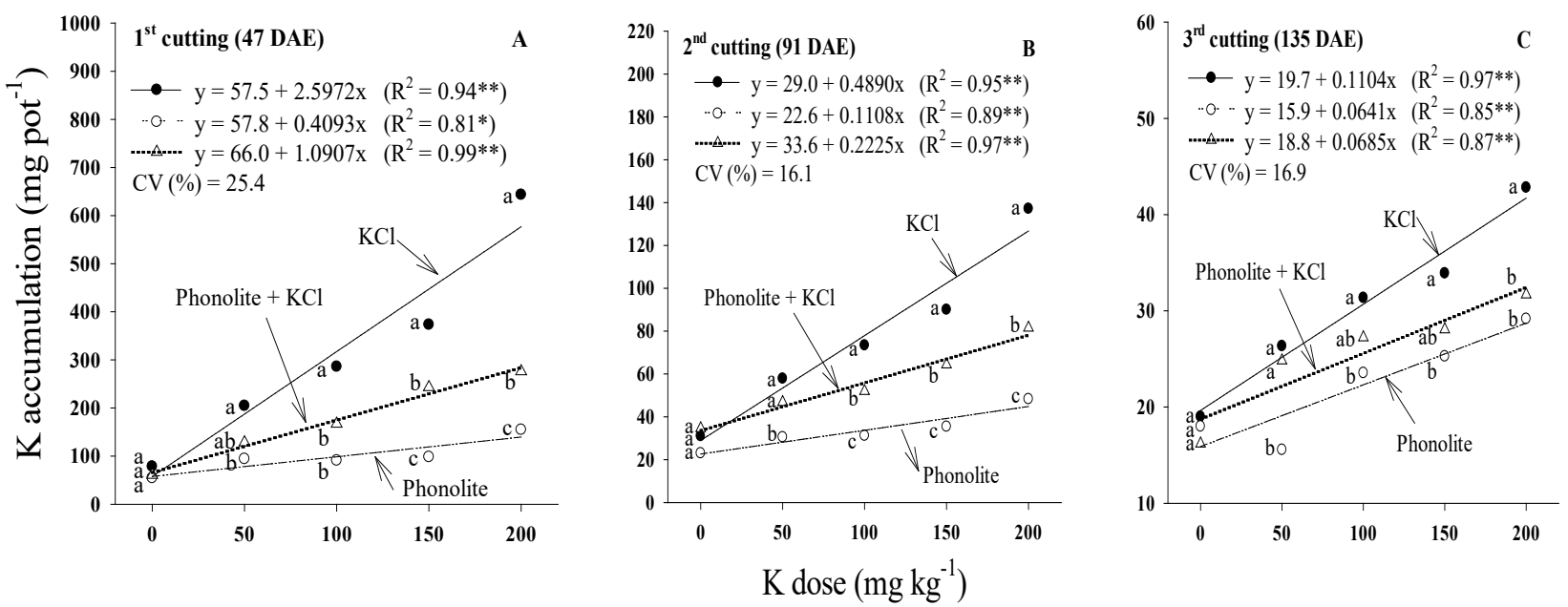

Figure 2. Potassium (K) accumulation in Paiaguás palisadegrass shoots, as a function of doses and sources, at three assessment times (A, B and C). Means followed by the same letter within each dose do not differ significantly according to the Tukey test at $5 \%$ of probability. ${ }^{* *}$ and $*$ : significant at $1 \%$ and $5 \%$ of probability, respectively. CV (\%): coefficient of variation. DAE: days after emergence.
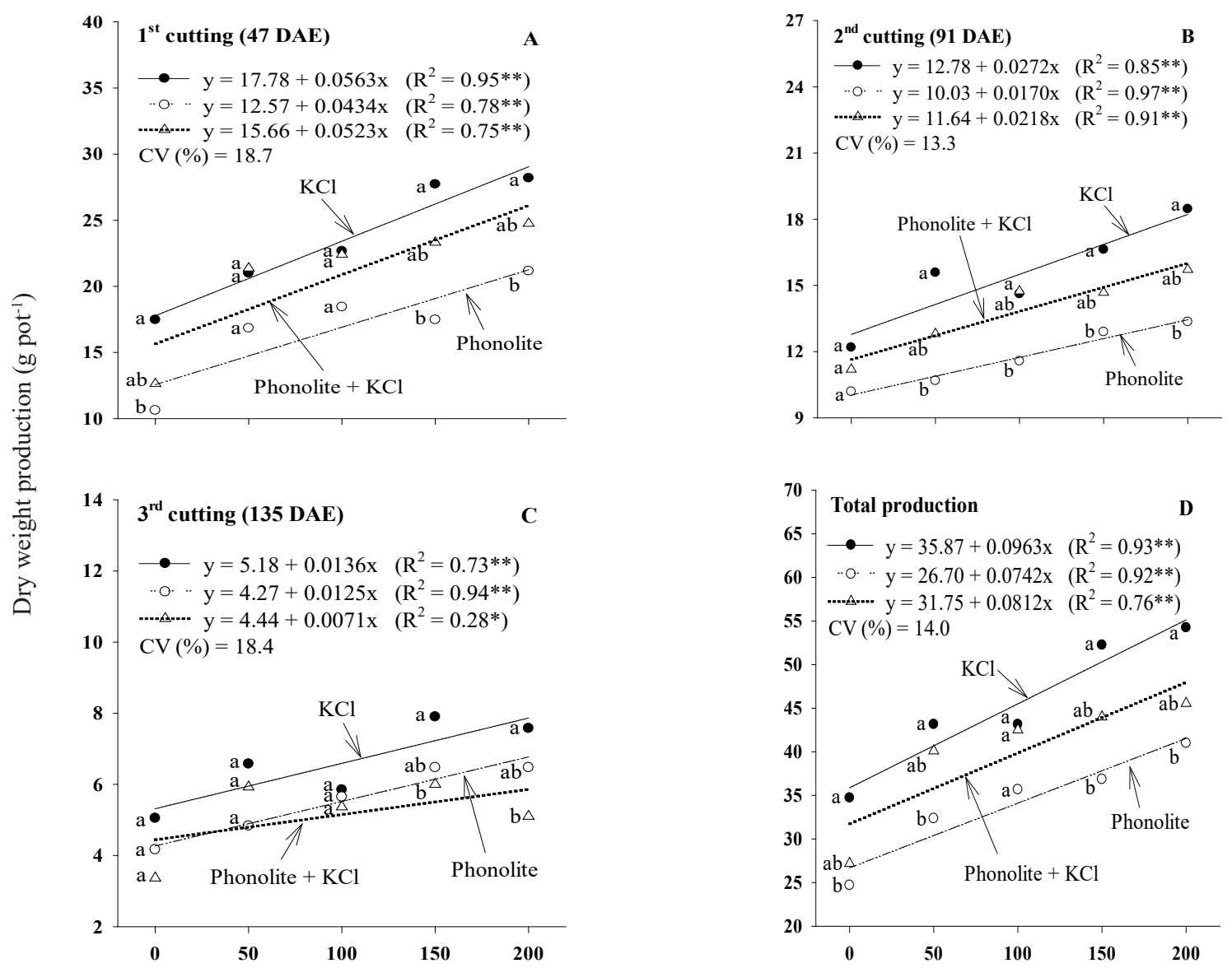

$\mathrm{K}$ dose $\left(\mathrm{mg} \mathrm{kg}^{-1}\right)$

Figure 3. Dry weight production of Paiaguás palisadegrass, as a function of K doses and sources at three assessment times (A, B and C) and for total yield over the study period (D). Means followed by the same letter within each dose do not differ significantly according to the Tukey test at $5 \%$ of probability. $* *$ and *: significant at $1 \%$ and $5 \%$ of probability, respectively. CV (\%): coefficient of variation. DAE: days after emergence. 
solution resulting from dissolved $\mathrm{KCl}$ (Figure 1A) may reduce the phonolite solubilization. Under these conditions, the transfer of structural $\mathrm{K}$ to the soil solution is minimal, because its concentration in the solution is far greater than the constant equilibrium of the mineral (Benites et al. 2010).

Given that the K content in the soil (Figures 1A, $1 \mathrm{~B}$ and $1 \mathrm{C}$ ) and plants (Figures 1D, 1E and 1F) did not increase with the phonolite application at all the three cuttings, but the $\mathrm{K}$ uptake and accumulation (Figures 2A, 2B and 2C) and dry weight production did (Figures 3A, 3B and 3C), it is believed that phonolite solubilization occurs slowly (Martins et al. 2015) during the forage growth cycle, largely via the action of organic acids exuded by the root system (Basak et al. 2017) and absorbed by the plants as they are released, so that no major changes in the soil $\mathrm{K}$ content as a function of $\mathrm{K}$ doses were observed at assessments conducted before each cutting.

The small or minimal influence of $\mathrm{K}$ doses on its concentration in the plants when phonolite was applied (Figures 1D, 1E and 1F) is likely due to the dilution effect. When $\mathrm{K}$ levels in the soil are low, its application promotes a heightened growth response in plants that is proportionally greater than the $\mathrm{K}$ uptake, preventing its concentration from increasing in plant tissues (Andrade et al. 2000).

As observed here, other authors have reported the beneficial effect of potassium fertilization on dry weight production in $U$. brizantha (Orioli Júnior \& Coutinho 2009, Megda \& Monteiro 2010, Morais et al. 2016) and that $\mathrm{KCl}$ is a fertilizer more efficient than phonolite (Bianchini \& Marques 2019, Boldrin et al. 2019). Given the low efficiency of phonolite, adding $30 \%$ of $\mathrm{KCl}$ to the blend to provide the $\mathrm{K}$ needed for initial plant growth was insufficient to produce the same amount of dry weight obtained with the application of the water-soluble source $(\mathrm{KCl})$ alone.

The number of tillers remained constant at the first cutting, regardless of the $\mathrm{K}$ dose and source (Figure 4A). This may indicate less initial dependence on the nutrient for tillering, since the potassium fertilization did not influence the number of tillers in the second (except for $\mathrm{KCl}$ ) and third cuttings, and, in general, no differences were observed among the fertilizers (Figures 4A, 4B and 4C). The application of $112 \mathrm{mg} \mathrm{kg}^{-1}$ of $\mathrm{K}$ with $\mathrm{KCl}$ as source produced the highest number of tillers $\left(34\right.$ pot $\left.^{-1}\right)$ at the third cutting. The phonolite application resulted in a linear increase in this variable, as a function of greater $\mathrm{K}$ doses at the first cutting, with 29 tillers pot $^{-1}$, whereas a quadratic effect was observed at the third cutting, with the largest number of tillers $\left(30\right.$ pot $\left.^{-1}\right)$ obtained when $145 \mathrm{mg} \mathrm{kg}^{-1}$ of $\mathrm{K}$ were applied. However, for the fertilizer blend, the highest number of tillers was obtained for $128 \mathrm{mg} \mathrm{kg}^{-1}$ of $\mathrm{K}$ applied at the second cutting (31 pot $\left.^{-1}\right)$ and $130 \mathrm{mg} \mathrm{kg}^{-1}$ of $\mathrm{K}$ at the third cutting $\left(35\right.$ pot $\left.^{-1}\right)$.

On the other hand, the number of leaves was only influenced by $\mathrm{K}$ doses at the third cutting, and no differences were observed among the sources (Figures 4D, 4E and 4F). Under a quadratic effect, 118 and $121 \mathrm{mg} \mathrm{kg}^{-1}$ of $\mathrm{K}$ produced the highest number of leaves (160 and 159 pot $\left.^{-1}\right)$ for the $\mathrm{KCl}$ and fertilizer blend, respectively. This variable increased linearly when phonolite was applied, with the highest $\mathrm{K}$ dose $\left(200 \mathrm{mg} \mathrm{kg}^{-1}\right)$ resulting in 145 leaves pot ${ }^{-1}$. The fact that the number of leaves and tillering were affected by the treatments, particularly in the third cutting, may be related to the height at which the plants were cut (at the ground level), which could increase the plant dependence on nutrients in the soil over time.

Potassium may favor tillering and increase the number of leaves in forage grasses (Megda \& Monteiro 2010). However, in the present study, the influence of $\mathrm{K}$ doses and sources on these variables do not fully explain the variations observed for the dry weight production, which increased at all the three cuttings as a function of $\mathrm{K}$ doses, regardless of the source used. However, potassium fertilization can also increase the leaf area of forage grasses (Megda \& Monteiro 2010), what is certainly related to the dry weight results obtained.

The EqKCl equation indicated that the phonolite and the fertilizer blend were less efficient than $\mathrm{KCl}$ (Figure 5), due to the slow and limited release of the $\mathrm{K}$ present in the phonolite. The addition of $30 \%$ of $\mathrm{KCl}$ to supply the $\mathrm{K}$ needed for initial plant growth did not produce a similar effect to that observed for $\mathrm{KCl}$ alone. Pooled data for all the cuttings demonstrated that the use of $\mathrm{KCl}$ may provide the same yields obtained with phonolite and the fertilizer blend at a dose of $200 \mathrm{mg} \mathrm{kg}^{-1}$ by applying 29 and $63 \%$ of this dose, respectively. Thus, all the sources studied can be used to supply $\mathrm{K}$ to Paiaguás palisadegrass; however, the selection should take into account the necessary dose based 

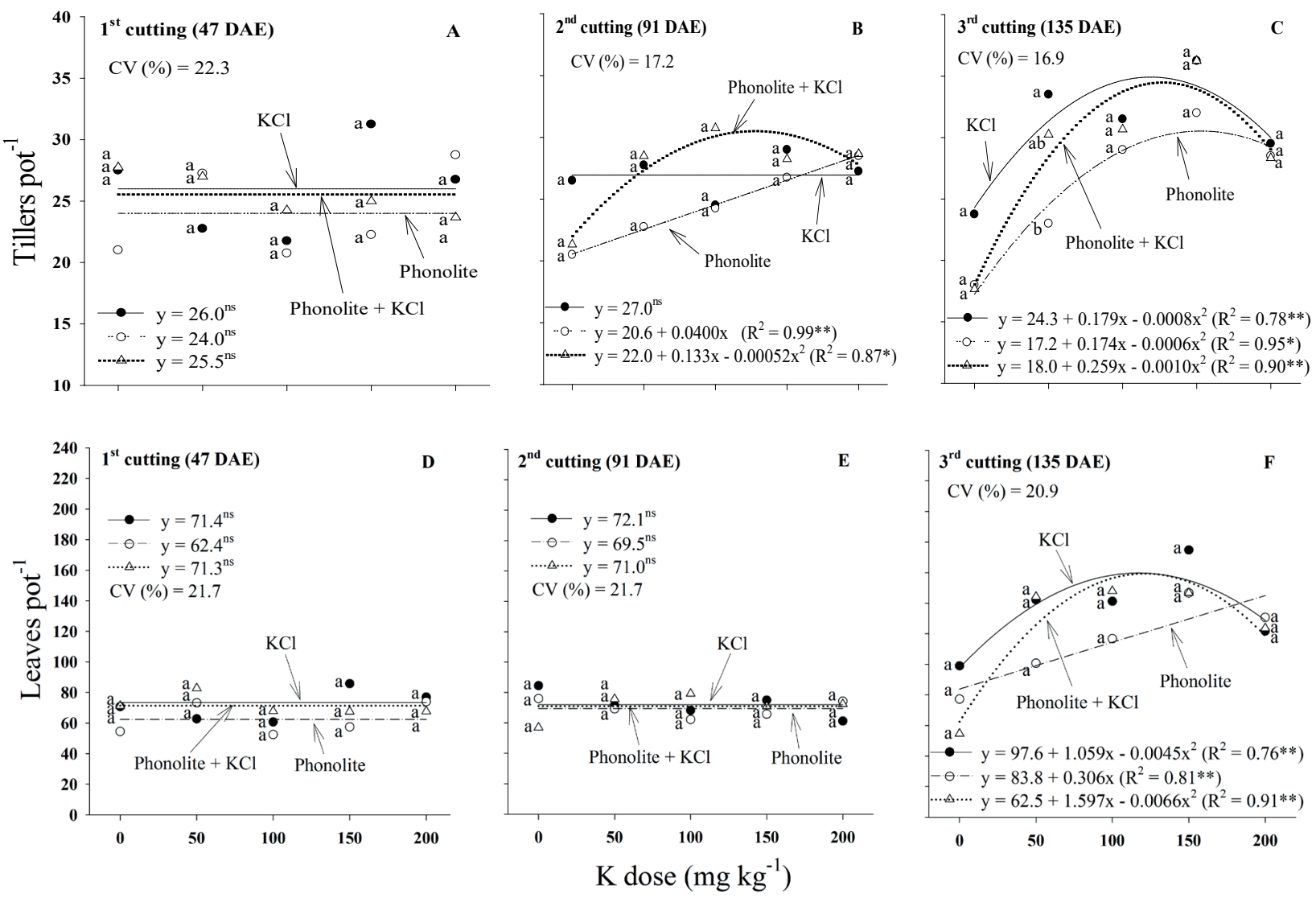

Figure 4. Number of tillers (A, B and C) and leaves (D, E and F) of Paiaguás palisadegrass, as a function of K doses and sources, at three assessment times. Means followed by the same letter within each dose do not differ significantly according to the Tukey test at $5 \%$ of probability. ${ }^{*}, *$ and ns: significant at $1 \%$ and $5 \%$ of probability and not significant, respectively. CV (\%): coefficient of variation. DAE: days after emergence.

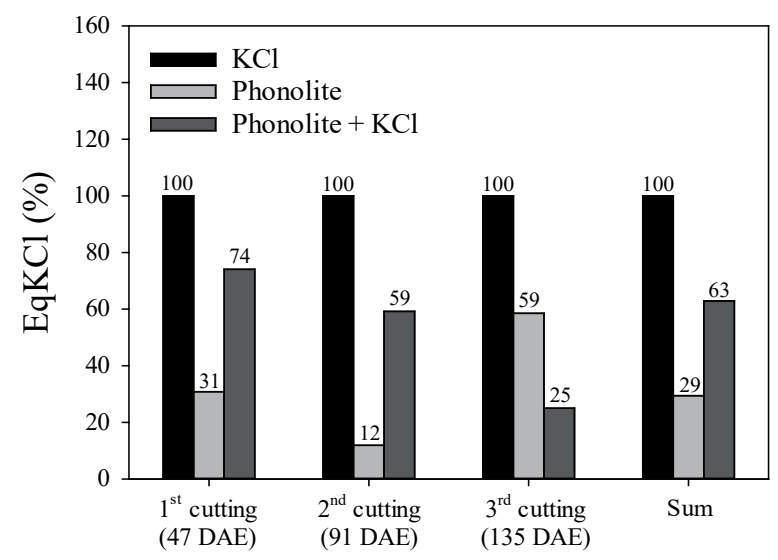

Figure 5. Average comparative agronomic efficiency with $\mathrm{KCl}$, as the reference source $(\mathrm{EqKCl})$ for each cutting and the sum of all the cuttings. DAE: days after emergence.

on its efficiency and the price per unit of nutrient for each fertilizer.
The obtained results support the calibration of soil chemical analysis and recommendations on managing the soil fertility using alternative sources. As a result, the critical $\mathrm{K}$ level was determined by establishing two classes of probable response to potassium fertilization (Figure 6).

The critical level of $1.4 \mathrm{mmol}_{\mathrm{c}} \mathrm{dm}^{-3}$ obtained is similar to the $1.53 \mathrm{mmol} \mathrm{dm}^{-3}$ reported by Orioli Júnior \& Coutinho (2009), for Marandu grass. Although critical levels have been established for annual crops, the value obtained here is also similar to those used in most the Brazilian states (Raij et al. 1997, Alvarez V. et al. 1999).

The critical K level for shoots was $8.7 \mathrm{~g} \mathrm{~kg}^{-1}$ (Figure 6), lower than the range suggested by Werner et al. (1997) for $U$. brizantha (12-30 $\mathrm{g} \mathrm{kg}^{-1}$ of K) and the value reported by Orioli Júnior \& Coutinho (2009) for Marandu grass (19.1 $\left.\mathrm{g} \mathrm{kg}^{-1}\right)$, likely due to the different nutrient requirements between species and cultivars. 

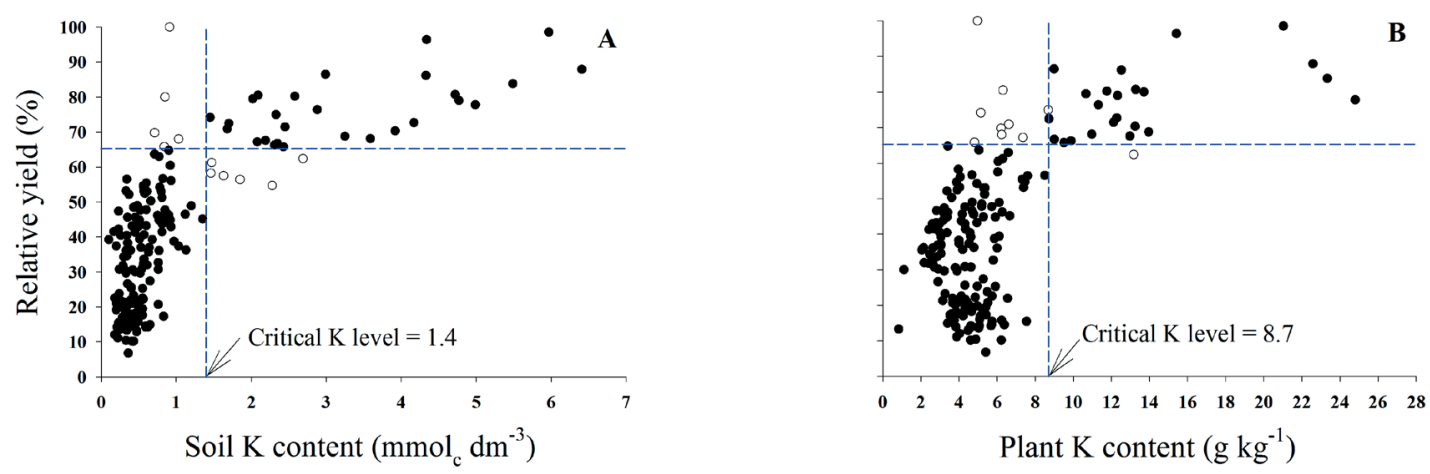

Figure 6. Critical K levels in the soil (A) and Paiaguás palisadegrass shoots (B).

\section{CONCLUSION}

Whether applied alone or in a fertilizer blend, phonolite was less efficient than $\mathrm{KCl}$ for all the cuttings (in a period of 135 days after emergence). On average, the agronomic efficiency for phonolite alone was $29 \%$, and $63 \%$ when mixed with $\mathrm{KCl}$. The critical K levels in the soil and Paiaguás palisadegrass shoots were $1.4 \mathrm{mmol}_{\mathrm{c}} \mathrm{dm}^{-3}$ and $8.7 \mathrm{~g} \mathrm{~kg}^{-1}$, respectively.

\section{REFERENCES}

ALVAREZ V., V. H.; NOVAIS, R. F. de; BARROS, N. F. de; CANTARUTTI, R. B.; LOPES, A. S. Interpretação dos resultados das análises de solos. In: RIBEIRO, A. C.; GUIMARÃES, P. T. G.; ALVAREZ V., V. H. (ed.). Recomendações para uso de corretivos e fertilizantes em Minas Gerais: $5^{\text {a }}$ aproximação. Viçosa: Comissão de Fertilidade do Solo do Estado de Minas Gerais, 1999. p. 25-32.

ANDRADE, C. A. de B.; FAQUIN, V.; FURTINI NETO, A. E.; ANDRADE, A. T.; CARNEIRO, R. F. V. Nutrição mineral do feijoeiro cultivado em solos de várzea do sul de Minas Gerais. Ciência e Agrotecnologia, v. 24, n. 4, p. 947-956, 2000.

BASAK, B. B.; SARKAR, B. Scope of natural sources of potassium in sustainable agriculture. In: RAKSHIT, A.; ABHILASH, P. C.; SINGH, H. B.; GHOSH, S. (ed.). Adaptive soil management: from theory to practices. Singapore: Springer, 2017. p. 247-259.

BASAK, B. B.; SARKAR, B.; BISWAS, D. R.; SARKAR, S.; SANDERSON, P.; NAIDU, R. Bio-intervention of naturally occurring silicate minerals for alternative source of potassium: challenges and opportunities. Advances in Agronomy, v. 141, n. 1, p. 115-145, 2017.
BATAGLIA, O. C.; FURLANI, A. M. C.; TEIXEIRA, J. P. F.; FURLANI, P. R.; GALLO, J. R. Métodos de análise química de plantas. Campinas: Instituto Agronômico, 1983. (Boletim técnico, 78).

BECK, H. E.; ZIMMERMANN, N. E.; MCVICAR, T. R.; VERGOPOLAN, N.; BERG, A.; WOOD, E. F. Present and future Köppen-Geiger climate classification maps at 1-km resolution. Scientific Data, v. 5, e180214, 2018.

BENETT, C. G. S.; BUZETTI, S.; SILVA, K. S.; BERGAMASCHINE, A. F.; FABRICIO, J. A. Produtividade e composição bromatológica do capimmarandu a fontes e doses de nitrogênio. Ciência e Agrotecnologia, v. 32, n. 5, p. 1629-1636, 2008.

BENITES, V. M.; CARVALHO, M. C. S.; RESENDE, A. V.; POLIDORO, J. C.; BERNARDI, A. C. C.; OLIVEIRA, F. A. Potássio, cálcio e magnésio. In: PROCHNOW, L. I.; CASARIN, V.; STIPP, S. R. (ed.). Boas práticas para uso eficiente de fertilizantes. Piracicaba: IPNI, 2010. p. 133-204.

BIANCHINI, H. C.; MARQUES, D. J. Sources of potassic fertilization in soybean production under different irrigation blades. Journal of Experimental Agriculture International, v. 37, n. 1, p. 1-8, 2019.

BOLDRIN, P. F.; SOUTO, H. F.; SALLES, L. S.; FURTINI NETO, A. E. Alternative sources of potassium for maize cultivation. Ciência e Tecnologia, v. 43, e023619, 2019.

BRASIL. Ministério da Agricultura, Pecuária e Abastecimento. Manual de métodos analiticos oficiais para fertilizantes e corretivos. Brasília, DF: MAPA, 2017.

BRIGHENTI, A. M.; SOUZA SOBRINHO, F.; ROCHA, W. S. D.; MARTINS, C. E.; DEMARTINI, D.; COSTA, T. R. Suscetibilidade diferencial de espécies de braquiária ao herbicida glifosato. Pesquisa Agropecuária Brasileira, v. 46, n. 10, p. 1241-1246, 2011.

CATE JUNIOR, R. B.; NELSON, L. A. A simple statistical procedure for partitioning soil test correlation data into 
two classes. Soil Science Society of America Proceedings, v. 35, n. 4, p. 658-659, 1971.

COSTA, K. A. P.; FAQUIN, V.; OLIVEIRA, I. P. Doses e fontes de nitrogênio na recuperação de pastagens do capimmarandu. Arquivo Brasileiro de Medicina Veterinária e Zootecnia, v. 62, n. 1, p. 192-199, 2010.

FERNANDES, F. R. C.; LUZ, A. B.; CASTILHOS, Z. C. Agrominerais para o Brasil. Rio de Janeiro: CETEM, 2010.

GERMANO, L. H. E.; VENDRUSCOLO, M. C.; DANIEL, D. F.; DALBIANCO, A. B. Produtividade e características agronômicas de Brachiaria brizhanta cv. Paiaguás submetida a doses de nitrogênio sob cortes. Boletim de Indústria Animal, v. 75, n. 1, p. 1-14, 2018.

GOEDERT, W. J.; REIN, T. A.; SOUSA, D. M. G. Eficiência agronômica de fertilizantes fosfatados não tradicionais. Brasília, DF: Embrapa-CPAC, 1986. (Documentos, 24).

INSTITUTO BRASILEIRO DE MINERAÇÃO (Ibram). Informações e análises da economia mineral brasileira. 6. ed. Brasília, DF: Ibram, 2011.

LOPES, A. S. Reservas de minerais potássicos e produção de fertilizantes no Brasil. In: YAMADA, T.; ROBERTS, T. L. Potássio na agricultura brasileira. Piracicaba: Potafos, 2005. p. 21-32.

MANNING, D. A. C. Mineral sources of potassium for plant nutrition. Sustainable Agriculture, v. 2, n. 1, p. 187203, 2011.

MARSCHNER, P. Marschner's mineral nutrition of higher plants. London: Academic Press, 2012.

MARTINS, V.; SILVA, D. R. G.; MARCHI, G.; LEITE, M. C. A.; MARTINS, E. de S.; GONÇALVES, A. S. F.; GUILHERME, L. R. G. Effect of alternative multinutrient sources on soil chemical properties. Revista Brasileira de Ciência do Solo, v. 39, n. 1, p. 194-204, 2015.

MEGDA, M. M.; MONTEIRO, F. A. Nitrogen and potassium supply and the morphogenic and productive characteristics of Marandu palisadegrass. Revista Brasileira de Zootecnia, v. 39, n. 8, p. 1666-1675, 2010.

MORAIS, L. P. V. X. C. de; BONFIM-SILVA, E. M.; PACHECO, A. B.; ABREU, J. G. de; SILVA, T. J. A. da; POLIZEL, A. C. Nitrogen and potassium in the cultivation of Piatã grass in Brazilian Cerrado soil. Revista Brasileira de Engenharia Agrícola e Ambiental, v. 20, n. 11, p. 984989, 2016.

MOREIRA, L. M.; MARTUSCELLO, J. A.; FONSECA, D. M.; MISTURA, C.; MORAIS, R. V.; RIBEIRO
JÚNIOR, J. I. Perfilhamento, acúmulo de forragem e composição bromatológica do capim-braquiária adubado com nitrogênio. Revista Brasileira de Zootecnia, v. 38, n. 9, p. 1675-1684, 2009.

ORIOLI JÚNIOR, V.; COUTINHO, E. L. M. Effectiveness of fused magnesium potassium phosphate for Marandu grass. Revista Brasileira de Ciência do Solo, v. 33, n. 6, p. 1855-1862, 2009.

RAIJ, B. V.; ANDRADE, J. C.; CANTARELLA, H.; QUAGGIO, J. A. Análise química para avaliação da fertilidade de solos tropicais. Campinas: Instituto Agronômico, 2001.

RAIJ, B. V.; CANTARELlA, H.; QUAGGIO, J. A.; FURLANI, A. M. C. (ed.). Recomendações de adubação e calagem para o estado de São Paulo. 2. ed. Campinas: Instituto Agronômico/Fundação IAC, 1997. (Boletim técnico, 100).

SANTOS, H. G. dos; JACOMINE, P. K. T.; ANJOS, L. H. C. dos; OLIVEIRA, V. A. de; LUMBRERAS, J. F.; COELHO, M. R.; ALMEIDA, J. A. de; ARAÚJO FILHO, J. C. de; OLIVEIRA, J. B. de; CUNHA, T. J. F. Sistema brasileiro de classificação de solos. 5. ed. Brasília, DF: Embrapa, 2018.

SANTOS, W. O.; MATIELLO, E. M.; COSTA, L. M. da; ABRAHÃO, W. A. P. Characterization of verdete rock as a potential source of potassium. Revista Ceres, v. 62, n. 4, p. 392-400, 2015.

SILVA, D. R. G.; MARCHI, G.; SPEHAR, C. R.; GUILHERME, L. R. G.; REIN, T. A.; SOARES, D. A.; ÁVILA, F. W. Characterization and nutrient release from silicate rocks and influence on chemical changes in soil. Revista Brasileira de Ciência do Solo, v. 36, n. 3, p. 951962, 2012.

SIQUEIRA, J. O.; GUEDES, G. A. A.; RIBEIRO, M. A. V. Disponibilidade do potássio do sienito nefelínico de Poços de Caldas, avaliada em cultivos sucessivos com milho. Pesquisa Agropecuária Brasileira, v. 20, n. 3, p. 299-307, 1985.

UNITED STATES DEPARTMENT OF AGRICULTURE (USDA). Soil Survey Staff. Keys to soil taxonomy. 12. ed. Washington, DC: Natural Resources Conservation Service, 2014.

WERNER, J. C.; PAULINO, V. T.; CANTARELLA, H.; QUAGGIO, J. A.; ANDRADE, N. O. Forrageiras. In: RAIJ, B. V.; CANTARELLA, H.; QUAGGIO, J. A.; FURLANI, A. M. C. (ed.). Recomendações de adubação e calagem para o estado de São Paulo. 2. ed. Campinas: Instituto Agronômico/Fundação IAC, 1997. p. 263-273. (Boletim técnico, 100). 